\title{
Continuous progeny testing, use and selection of proven bulls in Israel
}

\author{
R. BAR-ANAN
}

Institute of Animal Science, Volcani Research Centre, Bet Dagan, Israel.

\begin{abstract}
The breeding policy of the Israeli Holstein-type dairy cattle is reviewed. The bulls are progeny tested on their daughters' first three lactations. The traits evaluated are the following: milk, fat, yield persistency, fertility, incidence of mastitis, and \% cullings for three most important reasons. The test analysis takes into account the genetic level of daughters' contemporaries and maternal grandsires.

The paper describes a general outline of the selection decisions in AI bulls. Considerable amount of imported semen is used for breeding young bulls. Breeding goals are discussed against the estimated genetic parameters for and between the given traits.
\end{abstract}

\section{Introduction}

There is one dairy breed: The Israeli Holsteins. Fifty-five percent of the cows are milk recorded and virtually all of them are enrolled in A.I. 62,774 milk recorded cows yielded in 1981/82 8,340 kgs milk, $3.3 \%$ fat, $274 \mathrm{~kg}$ fat.

\section{Materials}

Progeny testing is carried out three times p.a. separately for each of the first three lactations. The following traits are evaluated: $\mathrm{kg}$ milk, $\mathrm{kg}$ fat, $\mathrm{kg}$ ECM (economical fat-corrected milk), $\%$ fat, $\%$ yield persistency, $\%$ conceptions of daughters, $\%$ incidence of mastitis and of $\%$ cullings for mastitis, low yield or infertility. Calving performance tests for direct and maternal effects on difficult calvings (DC) and perinatal calf mortality (CM) are computed separately for heifer calvings and combined for 2nd and 3rd parity calvings. ECM lactation yields $(\mathrm{Y})$ are converted to yields per day between calvings (DBC), annualized (365Y/DBC) and corrected for age, months of calving and days open. Lenght of calving interval when not available is computed by number of days open +277 . Incomplete lactations are extended to 305 days in milk and 60 days dry. Percent yield persistency is $100 \mathrm{Y} /(\mathrm{DBC} \times \mathrm{P})$, where $\mathrm{P}=$ peak yield, which is the mean $\mathrm{kg} \mathrm{ECM}$ at the 
two highest monthly recordings within 95 days post partum. The model for progeny testing yield traits takes into account the effects of the sires of the contemporaries and of the maternal grandsires. The computational procedure is similar to that used by USDA for MCC. The predicted differences (PD) for incidence characters (\%) are obtained by contemporary comparison.

In preparation are BLUP programs for testing calving performance, 8 linear conformation traits, milking speed and growth rate of bull calves by slaughter house data.

Fifty young bulls are brought annually into AI. In order to avoid inbreeding, two out of every five young bulls are by semen imported from selected sires, outside Israel. There is no import of bulls or cows and no import of semen beyond breeding part of the bull-dams. On average, five proven bulls are returned to service after progeny testing. The average life span of a proven bull is three years, so that there are about $12-15$ active proven bulls. Twentyfive percent of the inseminations in milkrecorded herds are by young bulls and the remainder by proven bulls. Heifers calve at two years of age and progeny tests are three times p.a., thus tests based on part-time lactations become available when the bulls are $4 \frac{1}{2}$ years old. At the age of five years, most of the bulls are already slaughtered and the very best ones returned to service.

Some considerations for adopting the procedures outlined were:

1) Three lactations are used for progeny testing, although the genetic correlation between 1 st and 2 nd lactation yields is about 0.8 (Table 4). This correlation is less among highly selected proven sires. Thus, ranking

Table 1. Effects of days open on current and following $\mathrm{ECM}^{(1)}$ yields in \% of modal group.

\begin{tabular}{|c|c|c|c|c|c|c|c|c|c|}
\hline \multirow{3}{*}{$\begin{array}{l}\text { Yield } \\
\text { Lactation } \\
\text { No. of lact. }\end{array}$} & \multirow{2}{*}{\multicolumn{2}{|c|}{$\frac{305 \text { day ECM }}{\text { Current }}$}} & \multicolumn{7}{|c|}{ Annualized ECM } \\
\hline & & & \multicolumn{3}{|c|}{ Current } & \multicolumn{2}{|c|}{ Following ${ }^{(2)}$} & \multicolumn{2}{|c|}{ Combined $^{(3)}$} \\
\hline & 1 & $2+3+4$ & 1 & 2 & 3 & 2 & 3 & $1+2$ & $2+3$ \\
\hline \multicolumn{10}{|l|}{ Days open } \\
\hline $31-45$ & -12.6 & -9.6 & -3.4 & .2 & 1.2 & -3.4 & -4.4 & -5.6 & -3.0 \\
\hline $46-60$ & -9.6 & -7.4 & -2.4 & .4 & 1.2 & -1.8 & -3.3 & -3.3 & -2.0 \\
\hline $61-75$ & -6.0 & -4.7 & -1.5 & .6 & .9 & -1.7 & -2.2 & -2.6 & -1.0 \\
\hline $76-90$ & -2.2 & -2.2 & -.8 & .2 & .5 & -.6 & -1.6 & -1.1 & -1.1 \\
\hline $91-105^{(4)}$ & - & - & - & - & - & - & - & - & - \\
\hline $106-120$ & 1.7 & 1.2 & - & -.7 & -.5 & -.5 & 1.0 & -.8 & - \\
\hline $121-135$ & 2.5 & 2.1 & .2 & -1.2 & -1.6 & 1.0 & 2.0 & .6 & .2 \\
\hline $136-150$ & 3.2 & 3.0 & .5 & -1.4 & -2.3 & 1.0 & 2.0 & .6 & -.3 \\
\hline $151-165$ & 3.8 & 3.9 & .6 & -1.4 & -2.5 & 1.5 & 2.0 & .9 & -.6 \\
\hline $166-180$ & 3.9 & 4.3 & .3 & -2.2 & -2.0 & 1.0 & 2.5 & -.2 & -1.2 \\
\hline $181-195$ & 4.1 & 5.0 & .8 & -.2 .2 & -2.7 & 1.0 & 4.5 & - & .5 \\
\hline Range & 16.7 & 14.6 & 4.2 & -2.4 & -3.9 & 4.4 & 8.9 & 6.5 & 3.5 \\
\hline
\end{tabular}

\footnotetext{
(1) Economical fat corrected milk

(2) Effect of previous days open and effect of calving age.

(3) Effects on current and following lactations, and value of calf (estimated loss: $0.02 \%$ annualized ECM per day open).

(4) Modal days open group.
} 
among proven sires may change after 2 nd lactation tests. A multi-trait BLUP procedure taking into account three lactations is planned.

2) Annualized yields take into account the production post 305 days and the variation in days dry. Annualized yields are much less affected by days open than 305 day yields (Table 1).

3) The difference between contemporary daughters of proven and young bulls is about $100 \mathrm{~kg} \mathrm{ECM} \mathrm{per} \mathrm{lactation.} \mathrm{By} \mathrm{keeping} 50$ bulls alive one and a half years longer than in Finland, we can inseminate $75 \%$ of the cows by proven bulls instead of $25 \%$ and increase the mean yield of the national herd by about $50 \mathrm{~kg}$ ECM. Since in the Holstein-Friesian breed the best sires in the world have become available for the sire-to-sire improvement path, this path has virtually become a constant and the success of breeding programs depends largely on making best use of the sire-to-cow path.

4) Young bulls are, as a rule, mated with first parity heifers in order to randomize progeny testing and to reduce DC. The main culling among bulls is during or after daughters' first lactation. The positively proven bulls are at return to service mated with nulliparous heifers for testing their direct effect on heifer calvings. This proof and the 2 nd lactation yield test coincide and are used for 2 nd stage culling. Heifer calving tests are no criterion for sire culling, but are used for nominating proven bulls for maiden heifer inseminations.

5) Progeny testing for rate of growth of bull calves was introduced 25 years ago and discontinued after 15 years of testing and sire index selection. Breeding for growth tended to increase DC in heifer calvings and to reduce milk yields of heifers when bred to calve earlier than two years of age (SOLLER et al. 1974), apparently due to change in rate of maturing.

\section{Results and Discussion}

The standard deviation (SD) between sires for PD of ECM yields were absolutely and percentage-wise larger in 2nd lactations than in first ones (Table 2). The genetic correlations ( $\mathrm{rg}$ ) between PD of half-sib sires and between sires and sons were according to genetic expectations for 2nd and 3 rd lactations, but much less for 1 st lactation (Table 3). This may be due to

Table 2. The Standard Deviations (SD) between Predicted Differences (PD) for Annualized ECM of sire groups.

\begin{tabular}{lccccc}
\hline \multirow{2}{*}{ Lactation } & \multicolumn{2}{c}{ SD between sires } & & \multicolumn{2}{c}{ SD in kg ECM between } \\
& Kg ECM & \% of mean & & $\begin{array}{c}\text { Half-sib } \\
\text { groups }\end{array}$ & $\begin{array}{c}\text { Sire of } \\
\text { sires }\end{array}$ \\
\hline First & 202 & 2.87 & & 60 & 158 \\
Second & 227 & 3.01 & & 110 & 180 \\
Third & 205 & 2.63 & & 97 & 188 \\
1st to 2nd & & & 68 & 156 \\
\hline
\end{tabular}


Table 3. Genetic associations between Predicted Differences for Annualized ECM.

\begin{tabular}{|c|c|c|c|c|}
\hline \multirow[b]{2}{*}{ Lactation } & \multicolumn{2}{|c|}{ Between half-sibs } & \multicolumn{2}{|c|}{ Regression of sons on sires } \\
\hline & $\mathrm{N}$ groups & $\mathrm{tg}_{\mathrm{g}}^{(1)}$ & $\mathrm{N}$ pairs & $b_{g}^{(2)}$ \\
\hline First & 37 & .09 & 19 & .37 \\
\hline Second & 34 & .28 & 16 & .41 \\
\hline Third & 25 & .25 & 11 & .51 \\
\hline 1st to 2 nd & 31 & .24 & 15 & .47 \\
\hline
\end{tabular}

(1) intra-class correlation

(2) regression

reduced genetic variation among sires of sires for first lactations, but as yet not for later ones (Table 2). Israeli cattle breeders apparently have chosen sires of sires with similar yield transmitting capacity for first lactation, although $2 / 5$ of the sires were bred by imported semen (BAR-ANAN et al. 1983 a). It appears that the selection efficiency on the sire-to-sire path for $1 \mathrm{st}$ lactations has reached a plateau, but that the selection of sires of sires with respect to 2 nd and 3rd lactations is as yet less uniform.

The genetic correlation between annualized ECM and yield persistency, and between yield persistency and daughter conception rate were both positive (Table 4A). It appears that cow conception and yield persistency were both functions of the ability to absorb the stress of high yields. The direct effect of daily $\mathrm{kg} \mathrm{ECM}$ prior to insemination on conception rate was negative, the regression was $0.26 \%$ conception $/ \mathrm{kg} \mathrm{ECM}$ in 1 st lactation and 0.2 in cow lactations, but no genetic antagonism was found (BAR-ANAN et al. 1983 b). Daughter conception rates are not considered in a selection index.

Table 4A. Genetic correlations $\left(\mathrm{r}_{\mathrm{g}}\right)$ between $\mathrm{PD}(>.6$ repeatability)

$4 A$ Between characters

\begin{tabular}{lcccc}
\hline Character & $\begin{array}{c}\text { Ann. } \\
\text { ECM }\end{array}$ & $\begin{array}{c}\% \\
\text { Pers. }\end{array}$ & $\begin{array}{c}\% \\
\text { Conc. }\end{array}$ & $\begin{array}{c}\% \\
\text { Cull. }\end{array}$ \\
\hline $\begin{array}{l}\text { Annualized ECM } \\
\text { \% yield persistency }\end{array}$ & 162 & .43 & .10 & -.61 \\
\% conception & 159 & 152 & .42 & -.29 \\
\% cullings & 168 & 161 & 157 & -.53 \\
\hline
\end{tabular}

$r_{g}$ above and number of sires below the diagonal.

$4 B$ Between lactations

\begin{tabular}{|c|c|c|c|c|c|c|}
\hline \multirow{2}{*}{$\begin{array}{l}\text { Lactations } \\
\text { Character }\end{array}$} & \multicolumn{2}{|c|}{1 st to 2 nd } & \multicolumn{2}{|c|}{ 2nd to 3 rd } & \multicolumn{2}{|c|}{1 st to $3 \mathrm{rd}$} \\
\hline & $\mathrm{N}$ sires & $r_{g}$ & $\mathrm{~N}$ sires & $r_{g}$ & $\mathrm{~N}$ sires & $\mathrm{r}_{\mathrm{g}}$ \\
\hline Annualized ECM & 136 & .81 & 76 & .85 & 76 & .59 \\
\hline$\%$ yield persistency & 112 & .52 & 63 & .78 & 65 & .46 \\
\hline$\%$ conception & 123 & .43 & 71 & .57 & 69 & .72 \\
\hline$\%$ cullings & 126 & .35 & 75 & .35 & 72 & .14 \\
\hline
\end{tabular}


The effect of days open on milk yields was not negative when the yield in the following lactation is considered (Table 1). Culling rates were negatively associated with milk yields (Table 4A), and also negatively associated with rear udder evaluation (BAR-ANAN \& RON 1983). Testing for culling rate is important because of the odd sire whose daughters produce very well, but have poor udders or other problems.

The genetic correlations between the rates of difficult calvings and perinatal calf mortality were very high and there were also positive correlations between the direct effects in heifer and cow calvings and between the maternal effects in heifer and cow calvings and between direct and maternal effects (Table 5). When the direct effect of the calf on DC and CM is independent of the effect of the cow on DC and CM, a genetic correlation of 0.5 is expected, since the calves of the daughters inherit half the direct effect. Israeli results (Table 5) and Finnish findings (LINDSTRÖM \& VILVA 1977) were in line with such a scenario. In contrast, negative genetic correlations between direct and material effects were documented in US investigations (MARTINEZ et al. 1981). US scientists postulated that the negative association was due to small calves which were born easily and became small cows which have difficulties in giving birth (THOMPSON et al. 1981). We think that the divergence between the findings is due to genetic $\times$ calving age interactions. Sixty percent of the heifers in Israel calve at less than 2 years of age. Small and easily born calves are apparently early maturing and as heifers calve easily when younger than 2 years, similarly to Jersey heifers. On the other hand, large calves are of late maturing type and may not yet be ready for calving at less than 2 years. A positive genetic correlation fits this scenario. In the US, heifers are bred at a later age and according to weight, thus the early maturing heifers may become too fat and be past the optimum age for easy calving, but late maturing heifers will be at the right age. Such a scenario would produce a

Table 5. Genetic correlations ( $\mathrm{r}_{\mathrm{g}}$ ) between difficult calvings (DC) and perinatal calf mortality (CM) of heifers and $\operatorname{cows}^{(1)}$ and between direct and maternal effects.

\begin{tabular}{llccc}
\hline Character & Associations & $\mathrm{N}$ sires & $\mathrm{r}_{\mathrm{g}}$ & $\mathrm{r}^{(2)}$ \\
\hline Heifer direct & DC:CM & 37 & .96 & .93 \\
Heifer maternal & DC:CM & 87 & .98 & .96 \\
Cow direct & DC:CM & 59 & .83 & \\
Cow maternal & DC:CM & 49 & .66 & \\
Direct DC & Heifers:cows & 33 & .94 & \\
Direct CM & Heifers:cows & 33 & .72 & \\
Maternal DC & Heifers:cows & 45 & .54 & \\
Maternal CM & Heifers:cows & 45 & .37 & \\
Heifer DC & Direct:maternal & 32 & .59 & .49 \\
Heifer CM & Direct:maternal & 32 & .64 & .56 \\
Cow DC & Direct:maternal & 30 & .13 & \\
Cow CM & Direct:maternal & 30 & -.15 & \\
\hline
\end{tabular}

(1) 2nd and 3rd calvings

(2) 14 sires (see Table 6). 
negative genetic correlation. We suggest that the inter-breed experience of breeding small-sized breeds early and large-sized breeds late is also relavant intra-breeds.

The issue of the ideal size of the dairy cow seems therefore associated with the locally best exonomic age for first breeding: small type heifers which calve at less than two years of age and large type heifers which calve at a later age.

We continued to investigate the genetic correlation between direct and maternal effects on DC in heifer calvings by looking at data of 14 extensively used sires which averaged over 3,000 calvings of heifer mates and 3,600 calvings of heifer daughters. Genetic correlations between direct and maternal effects were approximately 0.5 for both DC and CM (Table 5). Both heifer mates and daughters of four of the 14 bulls gave birth with little DC and CM, and mates and daughters of four other bulls gave birth with high rates of DC and CM (Table 6). The large divergence between the proofs, suggests an oligogenic background for DC and CM. In such a scenario progress through selection for DC and setbacks through selection for growth rates (SOLLER \& BAR-ANAN 1974) can quickly be realized.

Table 6. Extensively used sires ${ }^{(1)}$ with homologous direct and maternal effects on heifer calvings.

\begin{tabular}{|c|c|c|c|c|c|c|c|}
\hline \multirow{3}{*}{$\begin{array}{c}\text { Effects } \\
\text { Sire } \\
\text { No. }\end{array}$} & \multicolumn{3}{|c|}{ Direct } & \multicolumn{3}{|c|}{ Maternal } & \multirow{3}{*}{$\begin{array}{c}\text { Sum } \\
\begin{array}{c}\text { of } \\
\text { effects }\end{array}\end{array}$} \\
\hline & $\mathrm{N}$ & $\%$ & $\%$ & $\mathrm{~N}$ & $\%$ & $\%$ & \\
\hline & Calv. & DC & $\mathrm{CM}$ & Calv. & DC & $\mathrm{CM}$ & \\
\hline 730 & 7841 & -4.3 & -2.8 & 1755 & -2.2 & -2.5 & -11.8 \\
\hline 166 & 7132 & -1.8 & -1.5 & 7045 & -1.6 & -2.8 & -7.6 \\
\hline 477 & 1847 & -1.5 & -1.3 & 1079 & -1.7 & -2.1 & 6.6 \\
\hline 475 & 5446 & -1.1 & -1.7 & 2283 & -.3 & -1.1 & -4.2 \\
\hline 494 & 2088 & 2.6 & 2.7 & 2559 & 1.7 & 2.1 & 9.1 \\
\hline 683 & 625 & 3.0 & 4.6 & 954 & 2.2 & 2.1 & 11.9 \\
\hline 743 & 1974 & 3.4 & 3.3 & 1242 & 2.9 & 2.7 & 12.3 \\
\hline 441 & 924 & 1.1 & 1.1 & 6665 & 5.6 & 5.1 & 12.9 \\
\hline
\end{tabular}

(1) Among 14 extensively used sires.

\section{References}

BAR-ANAN, R. \& RON, M. 1983. Genetic correlation among progeny groups for type traits, milk yield, yield percistency and culling rates. J. Dairy Sci. (in press).

BAR-ANAN, R., RON. M. \& WIGGANS, G. R. 1983 a. Associations among progeny tests of single or pooled lactations. J. Dairy Sci. 66: 595-600.

BAR-ANAN, R., RON, M. \& WIGGANS, G. R. 1983 b. Associations among milk yield, yield percistency, conception and culling rates in Israeli Holstein dairy cattle. J. Dairy Sci. (submitted).

LINDSTRÖM, U. B. \& VILVA, V. 1977. Frequency of stillborn calves and its association with production traits in Finnish cattle breeds. Z. Tierz. Zuchtungsbiol. 94: 27-43. 
MARTINEZ, M. L., FREEMAN, A. E. \& BERGER; P. J. 1981. Genetic relationship between early calf mortality and calving difficulty. J Dairy Sci. 65. Supp. 1: 87.

SOLLER, M. \& BAR-ANAN, R. 1974. Correlated effects of selection for rate of gain in dairy cattle. 1st World Congr. on Genetics appl. to Livestock Prod. Madrid. Vol. 3: 689-691.

THOMPSON, J. R., FREEMAN, A. E. \& BERGER; P. J. 1981. Age of dam and maternal effects for dystocia in Holsteins. J. Dairy Sci. 64: 1603-1609.

Ms received November 18, 1983.

SELOSTUS

\section{Sonnien jatkuva jälkeläisarvostelu, käyttö ja valinta Israelissa}

R. Bar-Anan

Volcanin Tutkimuskeskus, Kotieläintieteiden laitos, Bet Dagan, Israel

Israelissa on vain yksi lypsykarjarotu, Israelin friisiläinen. Sonnit jälkeläisarvostellaan kolmesti vuodessa, erikseen kunkin kolmen ensimmäisen lypsykauden suhteen. Arvosteluun sisältyvät seuraavat ominaisuudet: maitomäärä, rasvamäärä, rasvan taloudellisen arvon suhteen korjattu maitomäärä, rasva-\%, pitkämaitoisuus, tyttärien tiinehtyvyys, utaretulehdustiheys sekä karsinta-\% utaretulehduksen, heikon tuotoksen tai hedelmättömyyden takia. Vaikeiden poikimisten ja vasikkakuolleisuuden yleisyys lasketaan erikseen hiehojen ja vanhempien lehmien poikimisista. Maitomäärät muunnetaan vastaamaan poikimisvälin keskimääräistä päivätuotosta ja kerrotaan 365:llä sekä korjataan iän, poikimiskuukauden ja tyhjäkauden pituuden suhteen.

Tuotosominaisuuksien arvostelumallissa otetaan huomioon parsitoverien isien ja tyttärien emänisien vaikutukset. Keinosiemennykseen otetaan vuosittain 50 nuorta sonnia. Sukusiitoksen välttämiseksi $40 \%$ nuorsonneista tuotetaan valikoidulla tuontispermalla. Mitään sonneja tai lehmiä ei tuoda maahan, eikä siementäkään muuta kuin sonninemille. Keskimäärin hyväksytään jälkeläisarvostelun jälkeen viisi sonnia. Näitä käytetään keskimäärin kolme vuotta. Neljäsosa tarkkailukarjojen siemennyksistä tehdään nuorsonnien, loput jälkeläisarvosteltujen sonnien spermalla. Nuorsonneja käytetään kerran poikineille lehmille. Sonnien pääasiallinen karsinta tapahtuu tyttärien 1 . lypsykauden aikana tai päätyttyä. 